\title{
Finger Millet (Eleusine coracana L. Gaertn.) Production System: Status, Potential, Constraints and Implications for Improving Small Farmer's Welfare
}

\author{
S. Sakamma ${ }^{1}$, K. B. Umesh ${ }^{1}$, M. R. Girish ${ }^{2}$, S. C. $\operatorname{Ravi}^{1}$, M. Satishkumar ${ }^{1} \&$ Veerabhadrappa Bellundagi ${ }^{1}$ \\ ${ }^{1}$ Department of Agricultural Economics, University of Agricultural Sciences, GKVK, Bangalore, Karnataka, \\ India \\ ${ }^{2}$ Department of Agricultural Marketing, Co-operation and Business Management, University of Agricultural \\ Sciences, GKVK, Bangalore, Karnataka, India \\ Correspondence: S. Sakamma, Department of Agricultural Economics, University of Agricultural Sciences, \\ Gandhi Krishi Vignan Kendra, Bangalore, Karnataka, India. E-mail: saksri09@gmail.com
}

Received: September 9, 2017

Accepted: November 17, 2017

Online Published: December 15, 2017

doi:10.5539/jas.v10n1p162

URL: https://doi.org/10.5539/jas.v10n1p162

The research is financed by Department of Biotechnology, Ministry of Science and Technology, Government of India.

\begin{abstract}
This article aims to investigate the growth in area, production and productivity, mapping of cultivation technologies, economics, potentials and constraints for area and production expansion of finger millet. The exponential growth rates, indicated that though there was deceleration both in area and production there was significant growth in productivity due to introduction of high yielding varieties. The respondents under different production system (rainfed and irrigated situation) were homogeneous with respect to the age and family size except land holding and education level. Finger millet possesses tremendous potential for product diversification and export. Mapping of cultivation technologies indicated that, farmers applied more fertilizers than recommended. Hence, there is a need to strengthen extension/outreach programmes to create awareness among farmers to use the optimum level of nutrients, which helps in reducing the cost incurred by farmers as well as subsidy burden on government. The existing procurement price for finger millet was Rs. 2100/q which failed to cover the cost of production under rainfed situation. In the total land holding, the area under finger millet accounted for major (64\%) share in rainfed situation and thus the procurement price must be fixed looking into the cost of production of rainfed (Rs. 2624/q) finger millet, which helps in improving the welfare of finger millet growing small farmers.
\end{abstract}

Keywords: finger millet, small farmers, production system, cost and returns

\section{Introduction}

\subsection{Introduction to the Problem}

Millets are one of the oldest foods known to humans but they were discarded in approbation of wheat and rice with urbanization and industrialization (http://www.millets.res.in). Millets are the imperative food and fodder crops in semi-arid regions that are predominantly gaining more relevance in the world (http://www.millets.res.in) They are mostly grown in marginal areas or under agricultural conditions where major cereals would fail to give sustainable yields (Global Facilitation Unit for Underutilized Species, 2014). The millets production in the World accounts for 30.73 million tonnes, out of which 11.42 million tonnes is produced in India accounting for $37 \%$ of total World production (http://www.fao.org). Millets produce multiple securities (food, fodder, health, nutrition and ecological) making them the crops of agricultural security (Millet Network of India-Deccan Development Society-FIAN, 2009). Minor millets (finger millet, foxtail, kodo millet, proso millet, little millet and barnyard millet) have received far less research and development recognition than other crops with regard to crop improvement, cultivation practices and utilization (Global Facilitation Unit for Underutilized Species, 2014).

India is the largest producer of various kinds of millets. Out of the total minor millets produced, finger millet (Eleusine coracana L. Gaertn.) (ragi) accounts for about $85 \%$ of production in India (Divya, 2011). Finger millet 
is grown in India, Srilanka, Nepal, parts of Africa, Madgaskar, Malaysia, Uganda and Japan (http://agritech.tnau.ac.in). In India, finger millet is cultivated over an area of 1.19 million hectares with a production of 1.98 million tonne giving an average productivity of $1661 \mathrm{~kg}$ per ha. Karnataka accounts for 56.21 and $59.52 \%$ of area and production of finger millet followed by Tamil Nadu $(9.94 \%$ and $18.27 \%)$, Uttarakhand (9.40\% and 7.76\%) and Maharashtra (10.56\% and 7.16\%), respectively (http://www.indiastat.com).

In Karnataka, finger millet is principally grown in Tumakuru, Hassan, Ramanagara, Kolar, Chikkaballapura, Mandya, Chitradurga, Bengaluru Rural, Chikkamagaluru, Mysuru, Bengaluru Urban, Chamarajnagar and Davanagere districts. Tumakuru district accounts for 22.7 and $18.6 \%$ of of area and production of finger millet followed by Hassan (11.3\% and 10.7\%), Ramanagara (10.4\% and 14\%) and Kolar (8.3\% and 9.8\%), respectively (http://des.kar.nic.in). Bengaluru Urban district is having the highest productivity of $3306 \mathrm{~kg}$ per hectare followed by Bengaluru Rural $(2,702 \mathrm{~kg} / \mathrm{ha})$.

Finger millet is the prime staple food consumed by majority of population in South Karnataka. Finger millet has manifold nutritional benefits, it has thirty times more calcium than rice (Millet Network of India-Deccan Development Society-FIAN, 2009). Finger millet straw is an extensive feed in the livestock sector. Finger millet is not a season bound crop and hence if moisture is available, can be cultivated throughout the year (http://www.agritech.tnau.ac.in). Millets are low water consuming crops. "The rainfall requirement for sorghum, pearl millet and finger millet is less than 25\% of sugarcane and banana and 30\% that of rice" (Millet Network of India-Deccan Development Society-FIAN, 2009). Finger millet grains have long storability even under normal conditions and have made them "famine reserves". This aspect is at most important as Indian agriculture suffers from vagaries of monsoon (Michaelraj \& Shanmugam, 2013). Millets are the promising ones for fighting hunger, malnutrition and for ensuring food and nutritional security for masses (Gupta, 2006). In spite of these admirable qualities and its importance in food and nutrition security at regional level the crop is neglected in our policies and programmes both at national and regional levels. With this backdrop, the present study is focused on investigating the growth in area, production and productivity of finger millet, costs and returns, profitability as well as the potentials and constraints for area and production expansion of finger millet. This helps in exploring the possibilities to augment the production of finger millet in areas where there is vast potential for finger millet cultivation aiming at improving the welfare of small farmers.

\section{Methodology}

The study uses both secondary (time series) as well as primary (filed level) data to address the issues outlined above. To analyze the economics of finger millet and to identify the constraints and potentials for development, the required primary data were collected from the randomly selected farmers (comprising largely small holders) using pre-tested and well-structured schedule through personal interview method for the year 2014-15. Tumakuru, Hassan, Ramanagara and Bengaluru rural districts of Karnataka (India) were selected for the survey as they are the major finger millet growing districts of Karnataka. From each district sixty sample farmers were selected randomly. Sixty sample farmers comprised of 30 rainfed and 30 irrigated finger millet growing farmers. Totally data was collected from 240 finger millet growing farmers. General information regarding socio-economic status, cropping pattern, cultivation technologies, cost and returns, potentials and constraints for area and production expansions was collected from the sample farmers. The data collection was exclusively based on the memory of the respondents. To assess growth in area, production and productivity of finger millet, the data for 30 years from 1984-85 to 2013-14 for all India and Karnataka State were collected from India Stat.

\subsection{Analytical Tools}

\subsubsection{Exponential Growth Model}

The exponential growth model was employed to find out the growth in area, production and productivity of finger millet. The Growth rates for area, production and productivity were computed for a period of 30 years from 1984-85 to 2013-14. The study period was divided into different periods considering the important developments that have taken place in agriculture namely, economic liberalization-1991, targeted public distribution system-1997 and national food security mission-2007. Exponential growth model was selected for the analysis as most of the time series data follow exponential trend. Similar approach was used by Kumar and Ranjan (1998), Kumawat and Meena (2005), Sakamma and Ananth (2011), Bairwa et al. (2012) and Vinayaka et al. (2014).

\subsubsection{Costs and Returns}

The costs were classified into variable and fixed costs. Variable cost/working capital includes cost of inputs (seed, farm yard manure (FYM), fertilizer), labour cost and interest on working capital. Fixed cost includes 
depreciation on farm implements, land revenue, rental value of land, managerial cost and risk premium. The gross return was arrived at by adding the income from main product (grain) and the by-product (straw).

The information pertaining to the cropping pattern, socio-economic status, cost and returns, profitability as well as the potentials and constraints for area and production expansions are presented in tables for better comprehension. In order to facilitate interpretation of findings, statistical measures like percentages and averages were used.

\section{Results and Discussion}

\subsection{Growth Rates of Finger Millet in Karnataka and India}

Growth rates for area, production and productivity were computed for a period of 30 years from 1984-85 to 2013-14. The study period was divided in to four periods (Table 1), period I (1984-85 to 1991-92), II (1992-93 to 1997-08), III (1998-99 to 2007-08) and IV period (2008-09 to 2013-14) considering the important milestones that have taken place in agriculture as mentioned in the previous section and having bearing on the development of finger millet crop (economic liberalization-1991, targeted public distribution system-1997 and national food security mission-2007) in the country.

Table 1. Growth in area, production and productivity of finger millet in Karnataka and India (\%)

\begin{tabular}{lll}
\hline Particulars & Karnataka & India \\
\hline Area $(000 \mathrm{ha})$ & & $-0.408^{* * *}$ \\
I $(1984-85$ to $1991-92)$ & $-1.616 \mathrm{NS}$ & $-2.420^{* * *}$ \\
II $(1992-93$ to $1997-98)$ & $-1.162 \mathrm{NS}$ & $-3.060^{* * *}$ \\
III $(1998-99$ to $2007-08)$ & $-3.084 *$ & $-4.981 * *$ \\
IV $(2008-09$ to $2013-14)$ & $-3.268 * * *$ & $-2.594 * * *$ \\
Overall $(1984-85$ to $2013-14)$ & $-1.811 * * *$ & \\
Production $(000$ tonne) & & $-0.170 \mathrm{NS}$ \\
I (1984-85 to $1991-92)$ & $-0.148 \mathrm{NS}$ & $-3.404 * *$ \\
II $(1992-93$ to $1997-98)$ & $-2.430 \mathrm{NS}$ & $-3.119 \mathrm{NS}$ \\
III $(1998-99$ to $2007-08)$ & $-2.841 \mathrm{NS}$ & $-5.404 \mathrm{NS}$ \\
IV $(2008-09$ to $2013-14)$ & $-2.305 \mathrm{NS}$ & $-1.274 * * *$ \\
Overall $(1984-85$ to $2013-14)$ & $-0.238 \mathrm{NS}$ & \\
Productivity $(\mathrm{kg} / \mathrm{ha})$ & & $0.236 \mathrm{NS}$ \\
I (1984-85 to $1991-92)$ & $1.492 \mathrm{NS}$ & $-1.004 \mathrm{NS}$ \\
II $(1992-93$ to $1997-98)$ & $-1.282 \mathrm{NS}$ & $-0.060 \mathrm{NS}$ \\
III $(1998-99$ to $2007-08)$ & $0.250 \mathrm{NS}$ & $-0.446 \mathrm{NS}$ \\
IV (2008-09 to $2013-14)$ & $0.308 \mathrm{NS}$ & $1.334 * * *$ \\
Overall $(1984-85$ to $2013-14)$ & $1.602 * * *$ & \\
\hline
\end{tabular}

Note. ${ }^{* * *}, * *, *$ indicates significant at $1,5,10 \%, \mathrm{NS}=$ Not significant.

\subsubsection{Growth in Area under Finger Millet}

The growth in area for the overall period (Table 1) indicated that, area under finger millet for India $(-2.594 \%)$ was declining at a faster rate compared to Karnataka (-1.811\%). Similar trend was observed during period I, II, III and IV. The introduction of the above said programmes during different time periods had a negative impact on finger millet area both in India and Karnataka. This is also evident from the Figures 1 and 2. The implementation of Targeted Public Distribution system and National Food Security Mission, the Minimum Support Price and procurement of major cereals (rice and wheat) with appreciable increase in price have adversely affected the area under finger millet in both Karnataka as well as India. 


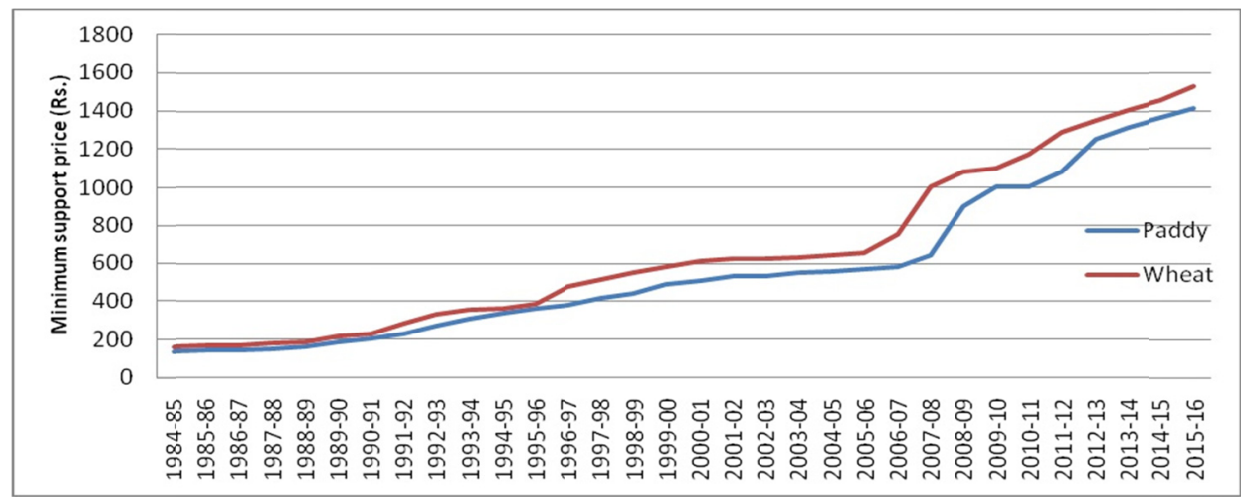

Figure 1. Minimum support price of paddy and wheat in India

Source: http://www.indiastat.com

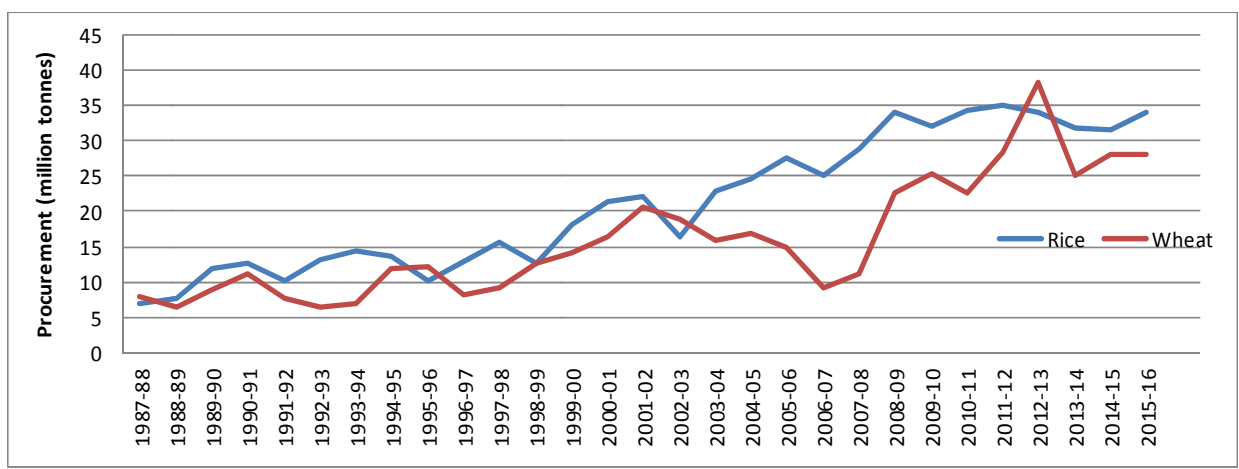

Figure 2. Procurement of rice and wheat under public distribution system in India

Source: http://www.indiastat.com

There was no significant decrease in area during I and II period in Karnataka. However, Karnataka being the major finger millet growing and consuming region traditionally, it has taken some time for reduction in area under finger millet. The reduction in area was significant only during III (-3.084\%) and IV (-3.268\%) period.

The decline in area of finger millet is also attributed to increased cost of cultivation and reduced returns. Acharya et al. (2012), in their study observed that, the growth in area under crops like jowar, bajra, finger millet and minor millets was negative, while growth in area under maize and rice was positive. They also observed that, there was a significant decrease in area under finger millet which might be due to low output price in the market.

\subsubsection{Growth in Production of Finger Millet}

The exponential growth rates for production of finger millet in India for the overall period 1984-85 to 2013-14 were $-1.274 \%$ per annum (Table 1). The decrease in production of finger millet in India during the study period was mainly due to decrease in area. Though there was negative trend in production of finger millet in Karnataka, it was not significant.

\subsubsection{Growth in Productivity of Finger Millet}

The growth in productivity of finger millet during overall period for both Karnataka (1.602\%) as well as India $(1.334 \%)$ indicated a positive and significant growth, though the overall period witnessed a significant decrease in both area as well as production. There was a significant growth in productivity in Karnataka during overall period due to the introduction of drought, finger and neck blast resistant and high yielding varieties (release of MR-1 in 1990, GPU-28 in 1998 and ML-365 in 2008). In Karnataka, the decrease in area to a certain extent was neutralized by the significant increase in productivity there by maintaining the production. Rajpurohit (1983) reported that there was a consistent growth in yield of finger millet in Karnataka during the period from 1976-77 to $1980-81$. 
Similarly, Kannan (2011) while analyzing the compound annual growth rates of area, production and productivity for major crops by States, found that finger millet registered negative growth rate in area and production except productivity across the States and at all India level. This implies that crop diversification is increasingly inclined towards commercial crops in the States resulting in shrinkage of area under coarse cereals and small millets.

After analyzing the trend in area, production and productivity of finger millet, the study focused on the status of finger millet crop in Karnataka along with the status of finger millet farmers.

\subsection{Production System and Status}

\subsubsection{Cropping Pattern in Karnataka}

The cropping pattern followed in rainfed and irrigated situations in the study area were distinct. Finger millet was an important crop in rainfed situation in kharif whereas, red gram was the major crop in irrigated situation. Finger millet was also grown as irrigated crop in Rabi season in the study area.

Table 2. Cropping pattern in the study area (ha)

\begin{tabular}{|c|c|c|}
\hline Crops & Rainfed situation & Irrigated situation \\
\hline \multicolumn{3}{|l|}{ Kharif } \\
\hline Finger millet & $87.40(53.92)$ & $11.72(04.37)$ \\
\hline Red gram & $08.40(05.18)$ & $22.90(08.54)$ \\
\hline Maize & $16.30(10.06)$ & $12.80(04.77)$ \\
\hline Groundnut & $06.20(03.82)$ & $05.80(02.16)$ \\
\hline Paddy & - & $21.70(08.09)$ \\
\hline Beans & - & $05.60(02.09)$ \\
\hline Horse gram & $01.01(00.68)$ & - \\
\hline Davana & - & $01.20(00.45)$ \\
\hline \multicolumn{3}{|l|}{$R a b i$} \\
\hline Finger millet & - & $44.7(16.68)$ \\
\hline Potato & - & $02(00.75)$ \\
\hline Maize & $14.20(08.76)$ & - \\
\hline Red gram & $12.70(07.83)$ & - \\
\hline Horse gram & $04.20(02.59)$ & $01.40(00.52)$ \\
\hline Vegetables & - & $10.30(03.84)$ \\
\hline Flowers & - & $01.60(00.60)$ \\
\hline Fodder maize & - & $05.80(02.16)$ \\
\hline \multicolumn{3}{|l|}{ Perennial } \\
\hline Grapes & - & $22.32(08.32)$ \\
\hline Mango & $11.60(07.16)$ & $28.96(10.79)$ \\
\hline Eucalyptus & - & $6.40(02.39)$ \\
\hline Arecanut & - & $17.80(06.63)$ \\
\hline Coconut & - & $17.40(06.49)$ \\
\hline Banana & - & $06.80(02.53)$ \\
\hline Mulberry & - & $16.40(06.13)$ \\
\hline Fodder grass & - & $04.60(01.72)$ \\
\hline Gross cropped area & $162.10(100)$ & $268.30(100)$ \\
\hline Net cropped area & 136.50 & 177.40 \\
\hline Cropping intensity (\%) & 118.80 & 151.30 \\
\hline
\end{tabular}

Note. Figures in parentheses indicate percentage to gross cropped area.

The cropping intensity (Table 2 ) was high in case of irrigated situation $(151.30 \%)$ compared to that of rainfed situation (118.80\%). The finger millet occupied highest share in gross cropped area among all the crops in rainfed situation $(53.92 \%)$ as it can withstand drought conditions, followed by maize $(18.82 \%)$, red gram (13.01\%) and mango (7.16\%).

In irrigated situation, the gross cropped area was high because of the availability of irrigation facility. Finger millet $(21.05 \%)$, red gram $(8.54 \%)$, paddy $(8.09 \%)$, mango $(10.79 \%)$, grapes $(8.32 \%)$, arecanut $(6.63 \%)$, coconut $(6.49 \%)$, and mulberry $(6.13 \%)$ were some of the important crops. Under irrigated situation, fodder maize and 
fodder grass was grown in order to meet the fodder requirement of livestock which consisted more number of cross bread cows (Table 4).

\subsubsection{Socio-Economic Characteristics of Finger Millet Farmers}

The average age of farmers of rainfed situation was 54 years while it was 53 years in irrigated situation. The classification of the farmer respondents according to their education level revealed that majority of farmers had primary education in both rainfed (38\%) and irrigated situation (41\%). In both, rainfed (28\%) and irrigated (30\%) situation farmers having secondary education occupied the second position (Table 3 ). With regard to average family size, it was same in both the situation (no. 5) and was statistically non-significant indicating that the contribution of family labour was same under both the situations.

With regard to land holding, the average size of land holdings was bigger in irrigated situation (1.48 ha) compared to rainfed situation (1.14 ha). Both under rainfed and irrigated situation majority of ragi growing farmers belong to small holders group. The area under finger millet in the total land holdings accounted for $64 \%$ in rainfed and $25 \%$ in irrigated situation.

The difference in the age and family size of the sample respondents was statistically non-significant revealing similarity between two situations except land holding and education level. These facts clearly showed that the selected farmer-respondents in rainfed and irrigated situation were homogeneous with respect to the socio-economic characteristics except land holding and education level.

Table 3. Socio-economic characteristics of finger millet farmers and assets position in rainfed and irrigated situations in Karnataka

\begin{tabular}{|c|c|c|c|}
\hline Particulars & Rainfed $(n=120)$ & Irrigated $(n=120)$ & 't' Value \\
\hline \multicolumn{4}{|l|}{ A. Socio-economic characteristics } \\
\hline I. Average age (Years) & 54.00 & 53.00 & $0.5004 \mathrm{NS}$ \\
\hline \multicolumn{4}{|l|}{ II. Literacy level (no.) } \\
\hline a. Primary (1-7) & $45(38)$ & $49(41)$ & \\
\hline b. High school (8-10) & $33(28)$ & $37(30)$ & \\
\hline c. College $(>11)$ & $14(12)$ & $20(17)$ & \\
\hline d. Illiterate & $28(22)$ & $14(12)$ & $-2.0091 *$ \\
\hline III. Average family size (no.) & 5 & 5 & $0.5227 \mathrm{NS}$ \\
\hline \multicolumn{4}{|l|}{ IV. Land holding } \\
\hline a. Marginal farmers $(<=1 \mathrm{ha})$ & $73(61)$ & $53(44)$ & \\
\hline b. Small farmers (1.1-2 ha ) & $47(39)$ & $67(56)$ & \\
\hline \multirow[t]{2}{*}{ Land holding (ha) } & 1.02 & 1.46 & \\
\hline & 0.12 & 0.02 & \\
\hline Average land holding (ha) cultivated & 1.14 & 1.48 & $-4.1687 * *$ \\
\hline Average area under finger millet (ha) & $0.73(64)$ & $0.37(25)$ & \\
\hline \multicolumn{4}{|l|}{ B. Livestock and farm assets inventory } \\
\hline \multicolumn{4}{|l|}{ I. Livestock position (no. of livestock) } \\
\hline a. Bullock pairs & 27 & 15 & $1.8005^{*}$ \\
\hline b. Cross bread cow & 44 & 182 & $5.5537 * *$ \\
\hline c. Local cows & 153 & 181 & $-1.1740 \mathrm{NS}$ \\
\hline d. Buffalo & 25 & 3 & $3.1388 * *$ \\
\hline e. Sheep & 136 & 115 & $0.2655 \mathrm{NS}$ \\
\hline f. Goat & 27 & 11 & $1.6664 \mathrm{NS}$ \\
\hline \multicolumn{4}{|l|}{ II. Farm assets (no. of farm assets) } \\
\hline a. Bullock cart & 12 & 1 & $3.1900 * *$ \\
\hline b. Seed drill & 8 & 3 & $1.5446 \mathrm{NS}$ \\
\hline c. Power tiller & 1 & 9 & $-2.610 \mathrm{NS}$ \\
\hline d. Tractor and accessories & 8 & 20 & $-2.4325^{* *}$ \\
\hline e. Irrigation pump (IP Set) and motor & 28 & 103 & $-11.0050 * *$ \\
\hline f. Tube well/Open well & 29 & 77 & $-6.5694 * *$ \\
\hline g. Farm building & 2 & - & $1.4202 \mathrm{NS}$ \\
\hline h. Cattle shed & 2 & 25 & $-4.9102 * *$ \\
\hline
\end{tabular}

Note. ${ }^{* *}, *$ : Significant at $1 \%$ and $5 \%$; NS $=$ not significant; Figures in parentheses indicate percentage to respective group total. 


\subsubsection{Average Annual Income of Finger Millet Growing Farm Households in Rainfed and Irrigated Situations}

The detail of annual income of farm households in rainfed and irrigated situation is furnished in Figures 3 and 4. In rainfed situation, finger millet growing farm households realized an annual income of Rs. 1,92,670 which $46 \%$ was from agriculture, $32 \%$ was from livestock, $15 \%$ was from non-farm and $7 \%$ from off-farm. Out of total agricultural income, finger millet accounted for a major share of $33 \%$, followed by perennials $(31 \%)$, other cereals $(21 \%)$ and pulses $(9 \%)$.

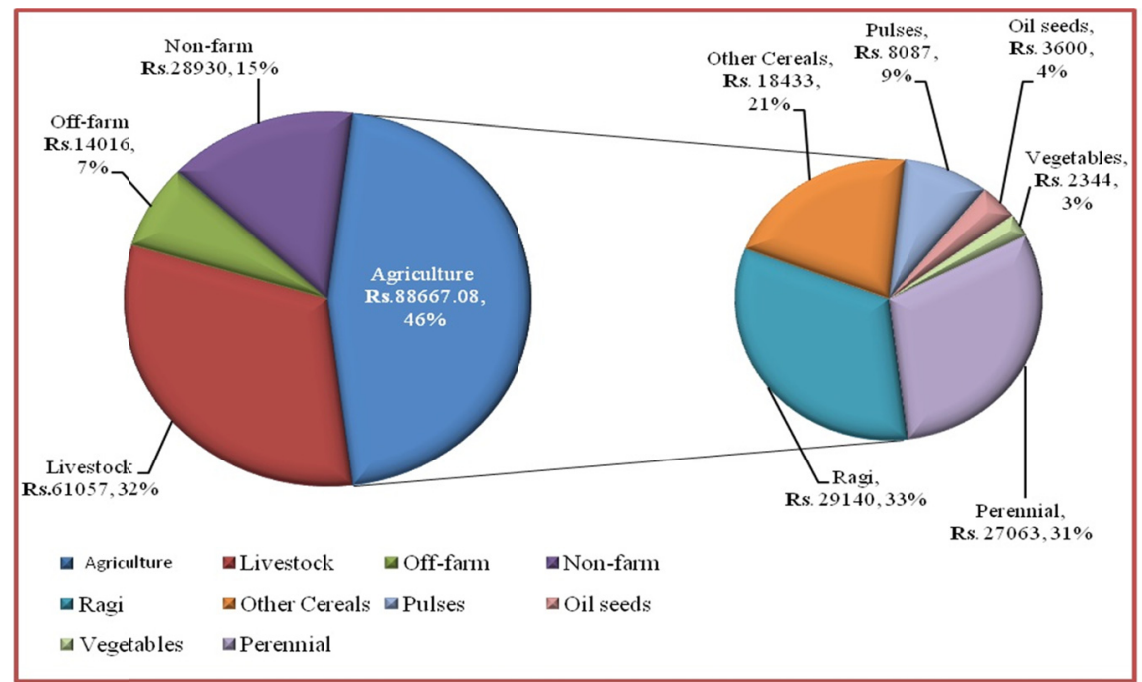

Figure 3. Average annual income of finger millet growing farm households - Rainfed situation

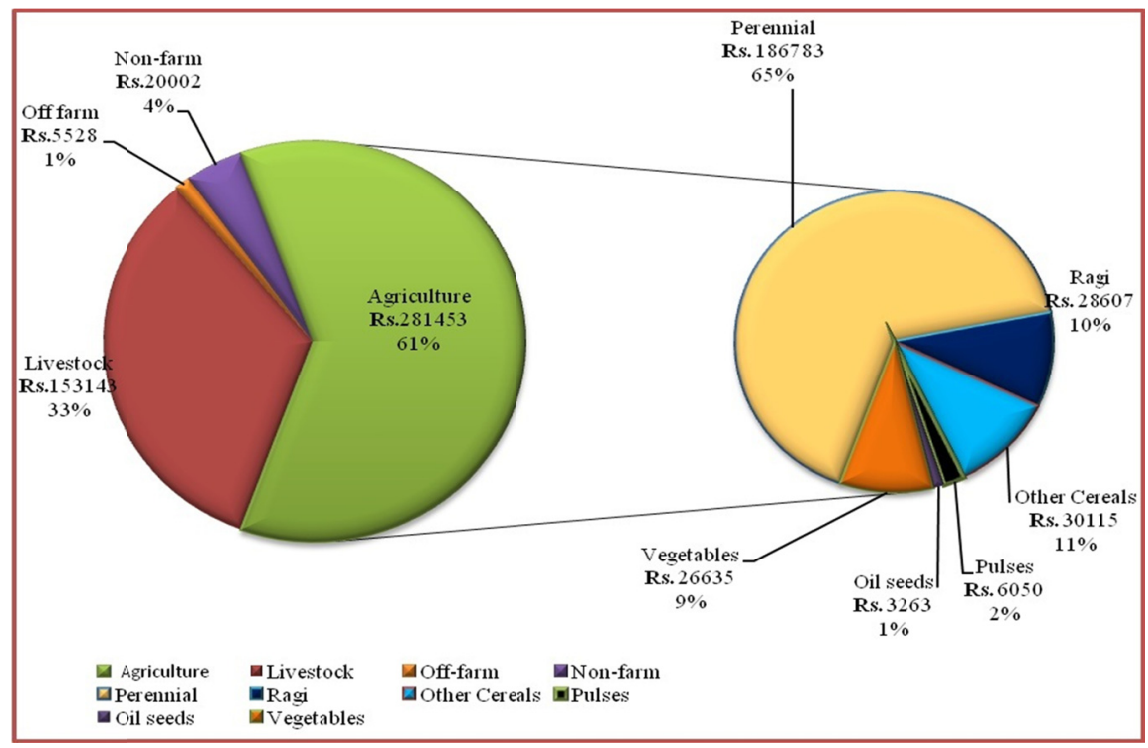

Figure 4. Average annual income of finger millet growing farm households - Irrigated situation

The finger millet growing farm households of irrigated situation realized an annual income of Rs. 4,60,127 of which $61 \%$ was from agriculture, $33 \%$ was from livestock, $4 \%$ was from non-farm sector. Out of the total agricultural income (Rs. 2,81,753), perennials contributed as high as $65 \%$, followed by other cereals (11\%) and finger millet (10\%).

Thus, livestock is becoming the major source of income next to agriculture, accounting for nearly $30 \%$ of their total income in both the situations. The findings of the study is in accordance with the study conducted by 
Government of Karnataka (2007), where it was reported that about $67 \%$ of farm income was from crop production and about $33 \%$ from livestock, fisheries and forestry.

\subsection{Mapping of Finger Millet Cultivation Technologies in Rainfed and Irrigated Situations in Karnataka}

Finger millet is one of the staple food crops in South India and has been cultivated for several years. Mapping of finger millet cultivation technologies helps to know the cultivation practices adopted by farmers. This helps in knowing the lacunas in the technologies followed by farmers and identify the gaps in some of the quantifiable variables in comparison with recommended practices.

Some of the cultivation practices identified were varieties used, field preparation (tillage, manuring), sowing (seed rate, seed treatment, preparation of nursery, method of sowing/planting), inter cultural operations (thinning, weeding, inter tillage, removal of foliage in case of lush green growth), irrigation, pest and disease management, harvesting (method and type), post harvest practices (threshing, drying and heaping and winnowing), post harvest treatment and crop rotation.

\section{(1) Varieties of Finger Millet Grown}

Both in rainfed and irrigated situation, GPU-28 was the major variety grown accounting for 70 and $41.7 \%$, respectively (Figure 5) followed by Indaf-5 (11.7\% and 30\%), Indaf-9 (4.2\% and $10.8 \%)$, Indaf-7 (5.0\% and $9.2 \%)$ and local $(9.2 \%$ and $8.3 \%)$.

The University of Agricultural Sciences, Bengaluru has recommended varieties suitable for different agro-climatic zones of South Karnataka considering soil type, distribution of rainfall, etc., such as long duration varieties viz. Indaf -8, MR-1, MR-6 and L-5; medium duration varieties viz. GPU-28, KMR-301, KMR-204, GPU-66, HR-911; short duration varieties viz. GPU-48, GPU-45, GPU-26, Indaf-9, KMR-204. All though, choice of varieties are available to farmers, majority of farmers cultivated GPU-28 as it bestowed better yield even under drought conditions and also it is resistant to finger and neck blast disease.
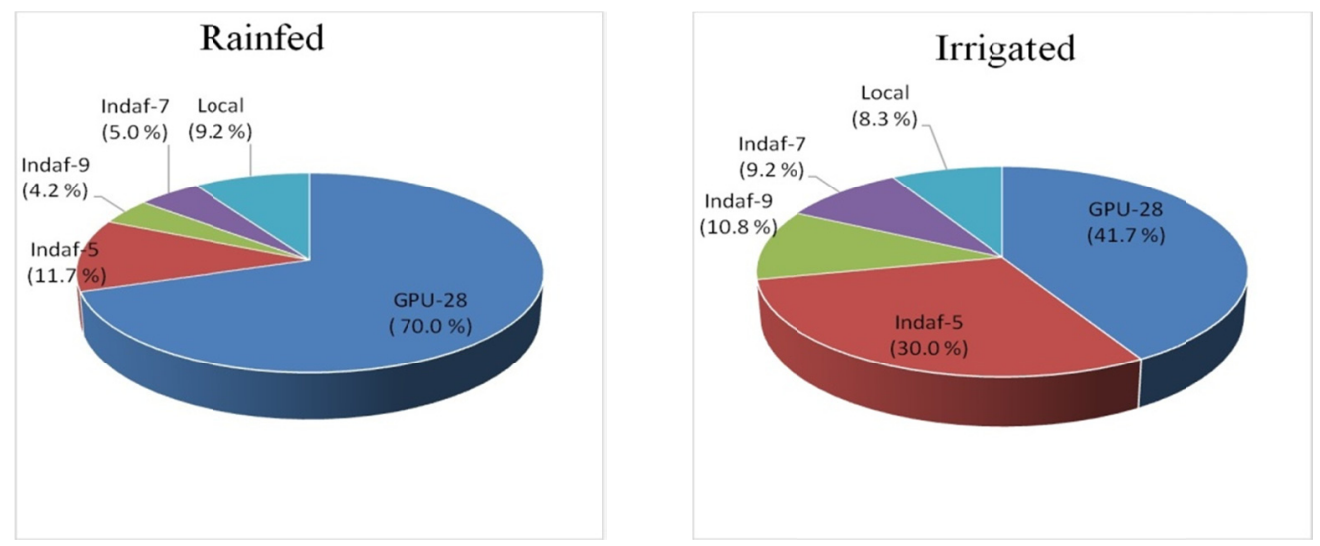

Figure 5. Ruling varieties of finger millet in rainfed and irrigated situations in Karnataka

(2) Field Preparation

a) Tillage: Primary and secondary tillage is being followed both in rainfed as well as in irrigated situation.

b) Application of manures

i) Farm yard manure: In rainfed situation, the farmers applied 3.25 tonne of FYM per ha whereas, in irrigated situation they applied 3.50 tonne per ha. In both rainfed $(7.5 \mathrm{t} / \mathrm{ha})$ and irrigated $(10 \mathrm{t} / \mathrm{ha})$ situations farmers were applying lower than recommended.

ii) Fertilizers: Both in rainfed (N: 105.2, P: 65.3, K: $1 \mathrm{~kg} / \mathrm{ha}$ ) and irrigated $(\mathrm{N}: 142, \mathrm{P}: 54.2, \mathrm{~K}: 1.3 \mathrm{~kg} / \mathrm{ha})$ situation (Figure 6), application of nitrogen and phosphorous was higher than the recommended dose (rainfed = $\mathrm{N}: 50, \mathrm{P}: 45, \mathrm{~K}: 40 \mathrm{~kg} / \mathrm{ha}$; irrigated $=\mathrm{N}: 100, \mathrm{P}: 50, \mathrm{~K}: 50 \mathrm{~kg} / \mathrm{ha}$ ). As farmers perceived higher application of fertilizers leads to higher yield. Whereas application of potash was found in traces because most of the farmers used Urea and Di-ammonium phosphate fertilizers which do not have potassium content. Hence, there is a need to strengthen extension/outreach programmes to create awareness among farmers to use the optimum level of nutrients, which helps in reducing the cost incurred by farmers as well as subsidy burden on government. 

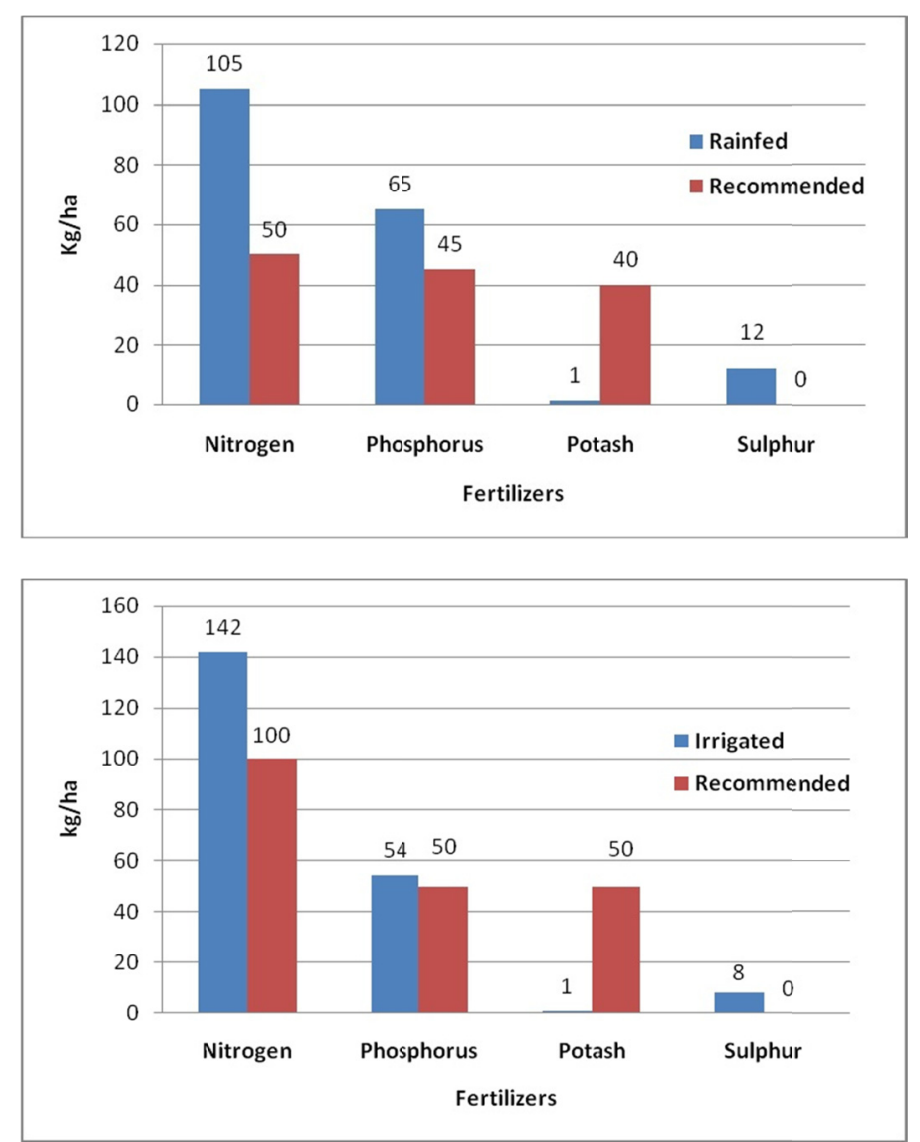

Figure 6. Application of fertilizers in rainfed and irrigated condition

iii) Micronutrient: Very few farmers applied micronutrients like Zinc, Boron and Gypsum; however, there is a recommendation to apply $750 \mathrm{~kg}$ of Zinc per hectare.

iv) Bio-fertilizers: None of the farmers applied bio- fertilizers, although there is a recommendation in package of practice to apply 150 gram of bio-fertilizer/azospirillum.

v) Method of manuring: Farmers followed two methods of manuring; broadcasting and line application. Manuring was done two times as basal dose and as top dressing. In case of basal dose $62.5 \%$ of farmers followed broadcasting and $37.5 \%$ followed line application in rainfed situation. Whereas in top dressing, $91.7 \%$ of farmers followed line application and $8.3 \%$ followed broadcasting (Figure 7).

Under irrigated situation, in case of basal dose, $46.7 \%$ of farmers followed broadcasting and $53.3 \%$ followed line application. Whereas, in top dressing, $76.7 \%$ of farmers followed line application and $23.3 \%$ followed broadcasting. 


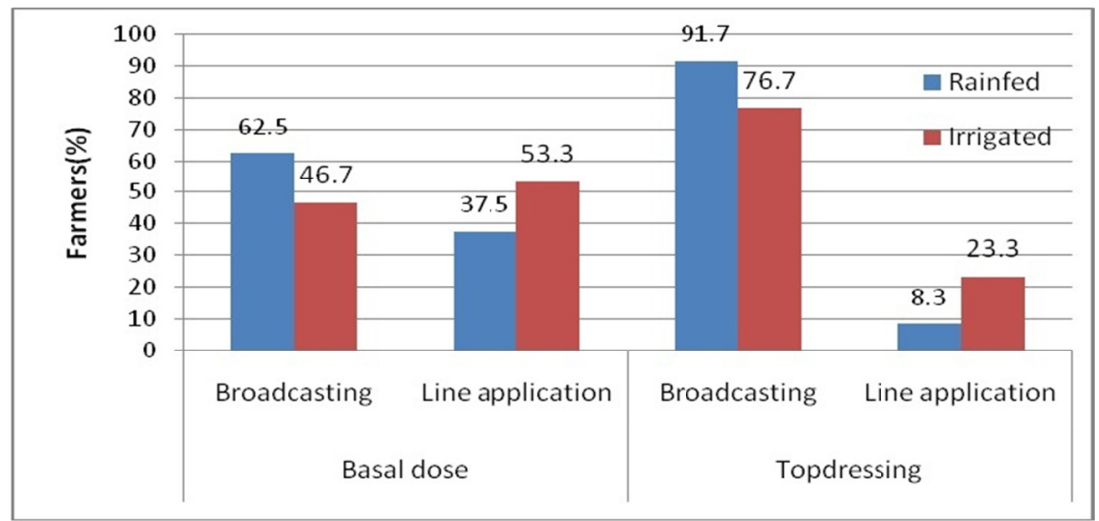

Figure 7. Application of manure in rainfed and irrigated condition

\section{(3) Sowing}

a) Seed rate: Is the quantity of seeds used per hectare. In rainfed situation $27 \mathrm{~kg}$ of seeds were used per hectare which was two times higher than the recommended $(12.5 \mathrm{~kg} / \mathrm{ha})$. Whereas in irrigated situation farmers were using seeds $(20.63 \mathrm{~kg} / \mathrm{ha})$ four times higher than the recommended $(5 \mathrm{~kg} / \mathrm{ha})$ (Figure 8). Farmers opined that if there is uneven germination, then the seedlings will be uprooted and transplanted in the gaps. Farmers also indicated that intercultivation will be done, which takes care of thinning or required plant population.
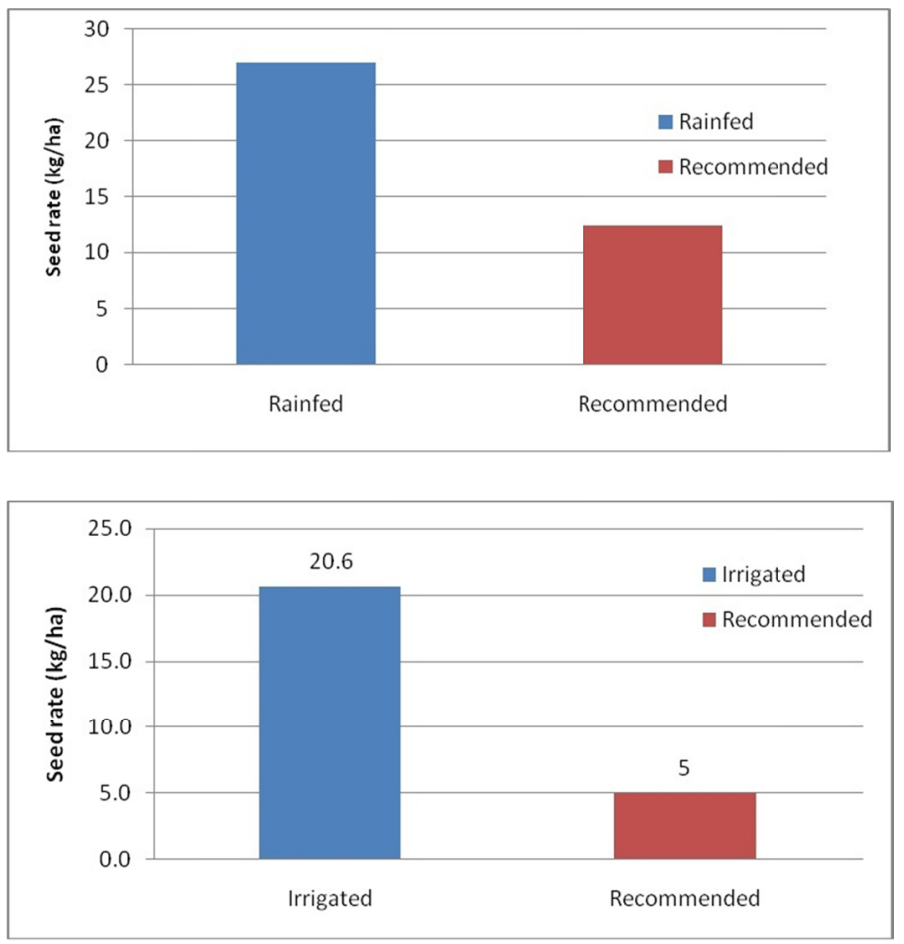

Figure 8. Seed rate in rainfed and irrigated condition

b) Seed replacement: Is a measure of total finger millet area sown with certified seeds in comparison to farm saved seeds. Both under rainfed and irrigated situations seed replacement rate was 30-35\%.

c) Seed treatment: Farmers were not practicing any seed treatment. Whereas, all Raitha Samparka Kendra distributed seeds were treated. 
d) Nursery preparation: A seed bed of 0.0340 and 0.0330 ha was prepared in rainfed and irrigated situation, respectively. However, recommended seed bed size was 0.0379 ha.

e) Age of seedlings for transplanting: Transplanting of seedlings was done after 25 days after sowing in nursery in both rainfed as well as irrigated situation and the recommended days of transplanting is 18 to 25 days.

f) Method of sowing/planting adopted by farmers: In irrigated situation majority of farmers adopted transplanting seedlings from nursery $(66.7 \%)$, followed by broadcasting $(17.5 \%)$, line sowing using seed cum fertilizer drill (7.5\%), line sowing using seed drill (5.8\%) and line sowing manually (2.5\%) (Figure 9).

In rainfed situation, broadcasting (34.2\%) was the most common method practiced, followed by line sowing manually $(24.2 \%)$, transplanting seedlings from nursery $(14.2 \%)$, line sowing using seed cum fertilizer drill $(14.2 \%)$ and line sowing using seed drill (13.3\%).

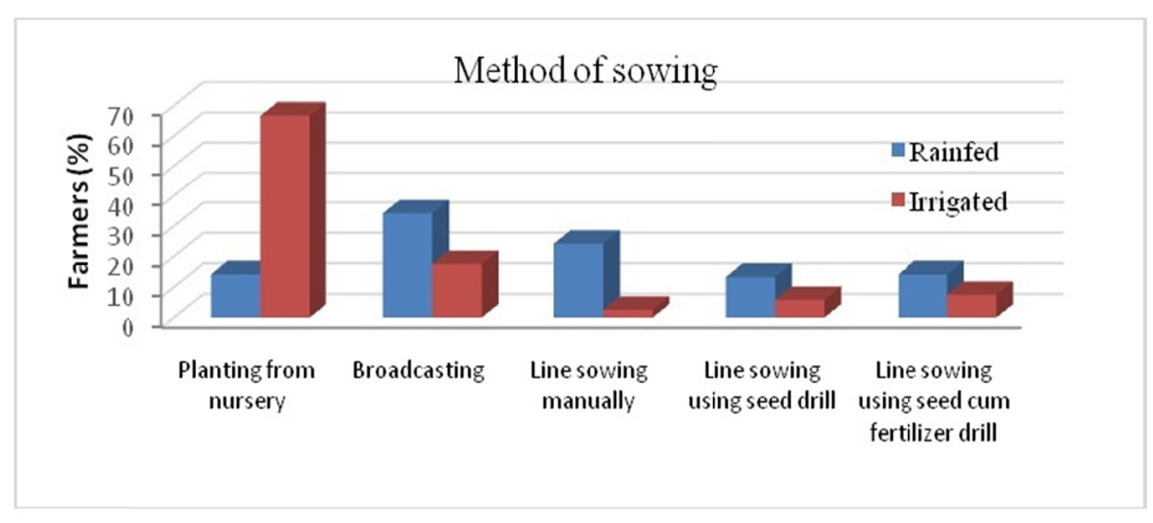

Figure 9. Method of sowing adopted by farmers

(4) Intercultural operations

Thinning and weeding: In rainfed situation, inter cultivation was performed five times whereas, under irrigated situation it was performed three times. Package of practice recommends two to three inter cultivation and application of Butachlor weedicide to control weeds.

(5) Irrigation: Under irrigated situation on an average the crop was irrigated eight times.

(6) Pest and disease management: Blast and Stem borer was prevalent in the study area and no management practice was followed in both the situations as the pest and disease was not much severe.

\section{(7) Harvesting}

a) Method of harvesting: Irrespective of rainfed and irrigated situation, manual harvesting was followed by all farmers.

b) Type of harvesting: There are two methods of harvesting followed in the study area. Cutting earhead alone and cutting earhead along with straw. In rainfed situation, $77 \%$ of farmers harvested earhead along with straw, followed by harvesting earhead alone (23\%). Likewise, under irrigated situation, $57 \%$ of farmers practiced cutting earhead along with straw and $43 \%$ of farmers harvested earhead alone (Figure 10). When farmers cut earhead alone, the threshing was done by using machine. 


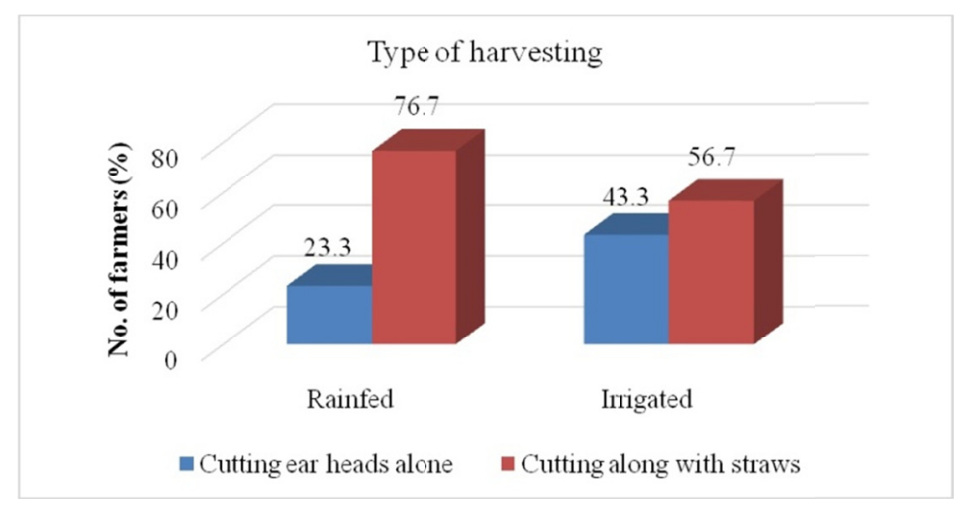

Figure 10. Type of harvesting practiced by farmers in the study area

(8) Post-harvest practices

a) Threshing: Around $60 \%$ of farmers used tractor for threshing in rainfed situation and it was $57 \%$ in irrigated situation. This was followed by threshers in rainfed (28.33\%) and irrigated (37.50\%) situations.

b) Winnowing: In rainfed situation $53 \%$ of farmers were dependent on wind for winnowing and in irrigated situation, it was $58 \%$.

c) Heaping and drying: If straw was cut along with the ear head then it was dried for 31 days and if ear head alone was harvested, it was dried for seven days and the straw was dried for 12 days under rainfed situation. In case of irrigated situation, when earhead was cut along with straw, it was dried for 33 days, this was done to achieve uniform coloration of ear heads. If ear head alone harvested, then it was dried for eight days and the straw was dried for six days.

d) Storage: Polypropylene bags were used to store finger millet grains in both rainfed $(80.8 \%)$ and irrigated (75\%) situation.

(9) Post harvest treatment: None of the farmers followed any post harvest treatment as there was no storage pests observed. It was opined by farmers that finger millet grains have long storability under normal conditions.

(10) Crop rotation: refers to practice of growing different crops in a planned sequence from season to season within a year or from year to year. Under rainfed situation finger millet was rotated with aware, red gram, maize and field bean. In Irrigated situation, it was grown in rotation with crops like red gram, maize, paddy and fodder jowar. Crop rotation helps in improving soil fertility there by reducing fertilizers application.

\subsection{Cost and Returns of Finger Millet in Rainfed and Irrigated Situation}

\subsubsection{Cost Structure in Finger Millet Cultivation}

The average working cost incurred in rainfed and irrigated finger millet cultivation was Rs. 38,566 per ha (Table 4) and Rs. 51,038 per ha (Table 6), respectively. Working cost constituted about $79.39 \%$ and $79.29 \%$ in rainfed and irrigated finger millet cultivation, respectively. Indicating that finger millet cultivation is less capital intensive. 
Table 4. Cost of cultivation of rainfed finger millet in Karnataka (hectare)

\begin{tabular}{|c|c|c|c|c|c|}
\hline Sl. No. & Particulars & Quantity & Unit cost (Rs) & Cost (Rs) & $\%$ \\
\hline \multirow[t]{9}{*}{ I } & Variable cost/working capital & & & & \\
\hline & Human labour (Mandays) & 66.18 & 200 & 13235 & 27.25 \\
\hline & Bullock labour (BP days) & 5.52 & 800 & 4416 & 9.09 \\
\hline & Machine labour (hours) & 11.25 & 745 & 8379 & 17.25 \\
\hline & Seed (kgs) & 23.53 & 16 & 371 & 0.76 \\
\hline & FYM (tonne) & 9.46 & 637 & 6024 & 12.40 \\
\hline & Fertilizer cost & & & 4837 & 9.96 \\
\hline & Interest on working capital at $3.5 \%$ & & & 1304 & 2.68 \\
\hline & Total variable cost/working capital & & & 38566 & 79.39 \\
\hline \multirow[t]{7}{*}{ II } & Fixed cost & & & & \\
\hline & Depreciation & & & 797 & 1.64 \\
\hline & Land revenue & & & 15 & 0.03 \\
\hline & Rental value of land & & & 4000 & 8.23 \\
\hline & Managerial cost @10\% of working capital & & & 3726 & 7.67 \\
\hline & Risk premium ( $2 \%$ of $80 \%$ working capital) & & & 617 & 1.27 \\
\hline & Total fixed cost & & & 9155 & 18.85 \\
\hline \multirow[t]{8}{*}{ III } & Cost of cultivation $(\mathrm{I}+\mathrm{II})$ & & & 47721 & 98.24 \\
\hline & Marketing cost & & & & \\
\hline & a. Packing and loading & & & 410 & 0.84 \\
\hline & b. Transportation & & & 239 & 0.49 \\
\hline & c. Weighing and unloading & & & 102 & 0.21 \\
\hline & d. Miscellaneous & & & 102 & 0.21 \\
\hline & Total cost of marketing & & & 854 & 1.76 \\
\hline & Total cost of cultivation & & & 48575 & 100.0 \\
\hline
\end{tabular}

Table 5. Returns from rainfed finger millet in Karnataka (hectare)

\begin{tabular}{|c|c|c|c|c|}
\hline & & Quantity & Price/Unit (Rs.) & Total (Rs.) \\
\hline \multirow[t]{6}{*}{ I } & Returns & & & \\
\hline & Main product (q) & 18.51 & 1602 & 29653 \\
\hline & By product (tonne) & 4.58 & 2287 & 10512 \\
\hline & Gross returns (Rs.) & & & 40165 \\
\hline & Net returns (Rs.) & & & -8410 \\
\hline & Cost of production (Rs./q) & & & 2624 \\
\hline II & Returns per rupee of expenditure & & & 0.83 \\
\hline
\end{tabular}

In rainfed finger millet cultivation, the major cost item in working cost was the cost on human labour (27.25\%) followed by cost on machine labour (17.25\%), FYM (12.40\%), fertilizer (9.96\%), bullock labour $(9.09 \%)$ and interest on working capital (2.68\%).

In irrigated finger millet cultivation, expenditure on human labour (29.20\%), followed by cost on machine labour (14.74\%), FYM (10.95\%), fertilizer cost $(8.70 \%)$, bullock labour $(7.53 \%)$, irrigation $(4.94 \%)$ and interest on working capital (2.68\%), were found to be the major costs.

Out of the total variable cost both in rainfed and irrigated situations, around 36\% was incurred only on the labour indicating that cultivation of finger millet is labour intensive. These findings are in line with the results of Lal and Sharma (2006), Pant and Srivastava (2014), and Jimjel et al. (2015). This clearly indicated that human labour was the most important input in finger millet cultivation, which is mainly required for activities such as sowing/transplanting, weeding, harvesting and post-harvest operations (threshing, cleaning and bagging).

Fixed costs accounted for $19 \%$ of the total cost of cultivation in rainfed and irrigated finger millet cultivation. Among fixed costs, rental value of land was major chunk in both rainfed $(8.23 \%)$ and irrigated $(7.77 \%)$ finger 
millet cultivation. The average fixed cost was Rs. 9,155 per ha and Rs. 11,979 per ha in rainfed and irrigated finger millet cultivation, respectively.

The average cost of cultivation of rainfed finger millet and irrigated finger millet was Rs. 48,575 and Rs. 64,369 per hectare, respectively. Cost of cultivation was high in irrigated situation compared to rainfed situation, because of more labour, FYM, fertilizer use besides irrigation cost and nursery.

\subsubsection{Returns from Finger Millet Cultivation}

The gross returns comprised returns from main product (grain) as well as by-product (straw/fodder). The average grain yield obtained per hectare under rainfed and irrigated situation was 18.51 quintals and 31.55 quintals (Tables 5 and 7), respectively. Per hectare gross returns were Rs. 40,165 and Rs. 67,007 in rainfed and irrigated finger millet cultivation, respectively.

The results indicated that, yield was high in irrigated situation compared to rainfed situation which was mainly because of the management practices like timely irrigation, optimum plant spacing, use of fertilizer and FYM. Irrigated finger millet also fetched higher price compared to rainfed finger millet because of off season production (produce would be ready for sale during the months of February to March during which market arrivals are less, resulting in high price for the produce).

The analysis of net return from finger millet cultivation revealed that the net return per hectare was negative i.e. Rs. 8,410 under rainfed situation (Table 5), whereas, the net return was Rs. 2,638 under irrigated situation (Table 7). Rainfed farmers realized negative net returns because of low yield and also high cost of cultivation. In spite of loss, farmers continue to grow finger millet mainly for the purpose of consumption and for the quantity and quality of the fodder that it provides. The cost of production was high in rainfed finger millet cultivation (Rs. 2,624 per quintal) compared to that of irrigated (Rs. 2,040 per quintal) finger millet cultivation due to low yield in rainfed situation. But the existing procurement price for finger millet was Rs. 2100 (Government of Karnataka) and Rs. 1650 per quintal (Minimum Support Price of Government of India) fails to cover the cost of production of finger millet under rainfed situation. In the total land holding, the area under finger millet accounted for major $(65 \%)$ share in rainfed situation, indicating finger millet is mainly cultivated as rainfed crop and thus the procurement price must be fixed looking into the cost of production of rainfed finger millet. The rate of return per rupee of expenditure incurred in rainfed and irrigated finger millet cultivation was found higher in case of irrigated (1.04) condition than in rainfed situation (0.83).

These results are in accordance with the study of Pant and Srivastava (2014), that the net returns from finger millet cultivation over all variable costs excluding family labour cost and including land revenue, depreciation and interest on working capital and imputed value of family labour) were negative indicating that the crop was cultivated only for subsistence and not for commercial purpose. Narayanamoorthy (2013) indicated that cultivation of finger millet under rainfed condition was not profitable. 
Table 6. Cost of cultivation of irrigated finger millet in Karnataka (hectare)

\begin{tabular}{|c|c|c|c|c|c|}
\hline Sl. No. & Particulars & Quantity & Unit cost (Rs) & Cost (Rs) & $\%$ \\
\hline \multirow[t]{10}{*}{ I } & Variable cost/Working capital & & & & \\
\hline & Human labour (Mandays) & 94.00 & 200 & 18796 & 29.20 \\
\hline & Bullock labour (BP days) & 6.06 & 800 & 4845 & 7.53 \\
\hline & Machine labour (hours) & 12.44 & 765 & 9486 & 14.74 \\
\hline & Seed (kgs) & 16.80 & 19 & 319 & 0.50 \\
\hline & FYM (tonne) & 10.50 & 675 & 7088 & 11.01 \\
\hline & Fertilizer (Urea, Complex) & & & 5600 & 8.70 \\
\hline & Irrigation charges (acre inch) & 15.89 & 200 & 3178 & 4.94 \\
\hline & Interest on working capital at $3.5 \%$ & & & 1726 & 2.68 \\
\hline & Total variable cost/working capital & & & 51038 & 79.29 \\
\hline \multirow[t]{7}{*}{ II } & Fixed cost & & & & \\
\hline & Depreciation & & & 1206 & 1.87 \\
\hline & Land revenue & & & 25 & 0.04 \\
\hline & Rental value of land & & & 5000 & 7.77 \\
\hline & Managerial cost at $10 \%$ of working capital & & & 4931 & 7.66 \\
\hline & Risk premium ( $2 \%$ of $80 \%$ working capital) & & & 817 & 1.27 \\
\hline & Total fixed cost & & & 11979 & 18.61 \\
\hline \multirow[t]{8}{*}{ III } & Cost of cultivation $(I+I I)$ & & & 63017 & 97.90 \\
\hline & Marketing cost & & & & \\
\hline & a. Packing and loading & & & 649 & 1.01 \\
\hline & b. Transportation & & & 379 & 0.59 \\
\hline & c. Weighing and unloading & & & 162 & 0.25 \\
\hline & d. Miscellaneous & & & 162 & 0.25 \\
\hline & Total cost of marketing & & & 1352 & 2.10 \\
\hline & Total cost of cultivation $(I+I I+I I I)$ & & & 64369 & 100.0 \\
\hline
\end{tabular}

Table 7. Returns from irrigated finger millet in Karnataka (hectare)

\begin{tabular}{lllll}
\hline & Quantity & Price/Unit (Rs) & Total (Rs) \\
\hline I & Returns & & \\
& Main product (q) & 31.55 & 1740 & 54897 \\
& By product (tonne) & 4.84 & 2502 & 12110 \\
& & & 67007 \\
& Gross returns (Rs.) & & 2638 \\
& Net returns (Rs.) & & 2040 \\
\hline Cost of production (Rs/q) & & 1.04 \\
\hline
\end{tabular}

\subsection{Potentials and Constraints for Area and Production Expansions}

\subsubsection{Strengths}

Finger millet is called as the powerhouse of health benefiting nutrients (http://www.thefitindian.com/) as it has highest amount of calcium ( $344 \mathrm{mg} / 100 \mathrm{~g}$ of finger millet), iron $(3.9 \mathrm{~g} / 100 \mathrm{~g}$ of finger millet) and minerals (2.7 $\mathrm{g} / 100 \mathrm{~g}$ of finger millet) (Millet Network of India-Deccan Development Society-FIAN, 2009). Due to its high content of polyphenols and dietary fiber, finger millet exhibits anti-diabetic and antioxidant and antimicrobial properties thus very much preferred by diabetic patients. Finger millet grains are malted and fed to infants, because of its high nutritional value. To produce one $\mathrm{kg}$ of finger millet only 1500 to 2000 liters of water is needed as against 4000 to 5000 liters of water to produce one $\mathrm{kg}$ of rice (The New India Express, 2015) thus the water requirement of the crop is low. Majority of farmers grow finger millet crop because of the fodder requirement for livestock as it is highly palatable to livestock. In finger millet crop the incidence of pest and diseases is very low thus limits the usage of pesticide, and mostly farm yard manure is applied in the production of finger millet thus by default forms environmental friendly crop (Figure 11).

\subsubsection{Weaknesses}

Lack of remunerative price which fails to cover the cost of cultivation and provide reasonable profit margin to farmers acts as disincentive to grow finger millet by farmers. The yield especially in rainfed finger millet is very 
low which leads to shift in crop. Low yield combined with low price leads to reduced returns is one of the main reasons for farmers reducing area under finger millet. Due to black/brown colour of finger millet the consumption of finger millet is less preferred by most of the people. Finger millet is the staple diet in southern Karnataka and hence its distribution is limited to specific region.

\subsubsection{Opportunities}

There is a high demand for finger millet malt due to its high nutritional value with appealing flavor and taste. There is vast scope for product diversification with almost 40 types of value added finger millet products that have already been developed by the University of Agricultural Sciences, Bengaluru. There is high potential for export of finger millet in the form of grain, flour and value added products. Finger millet has several nutritional benefits; research can contribute further to enhance these nutritional benefits.

\subsubsection{Threats}

Because of reduced return from finger millet, farmers are shifting from low value crops like finger millet to high value crops. Finger millet cultivation is labour intensive and high labour requirement is one of the reasons for increased cost of cultivation. Change in lifestyle leading to change in food habit with unappealing (colour, taste etc.) nature of finger millet, there is shift from finger millet to other food.

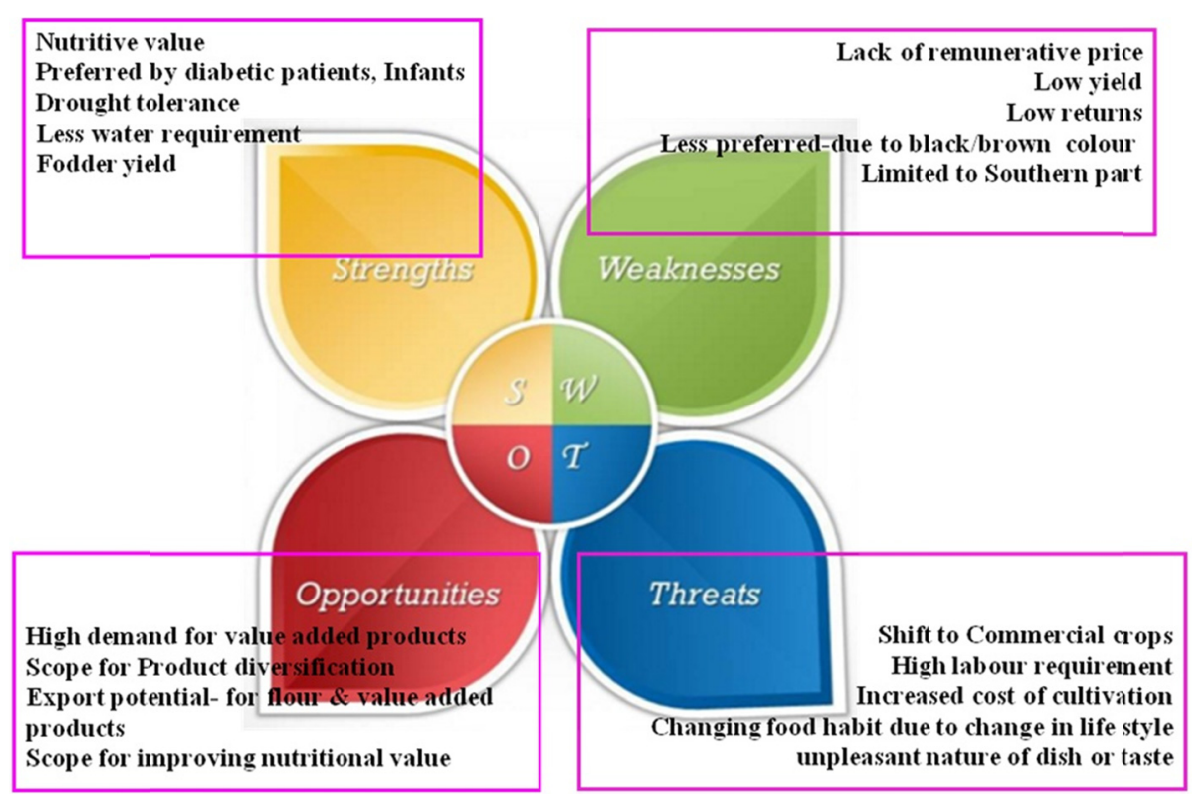

Figure 11. Potentials and constraints for area and production expansions

\section{Conclusion and Policy Recommendation}

The analysis indicated that there was significant decrease in both area as well as production of finger millet both in Karnataka and India. Though there was deceleration both in area and production there was significant growth in productivity during overall period due to introduction of high yielding varieties. Due to inclusion of finger millet in public distribution system there is increased demand for finger millet in Karnataka. As a result, there is higher scope to bring more area under finger millet cultivation in Karnataka. Hence, there is a need for more technological breakthrough in terms of release of drought resistant and high yielding varieties to enhance the production.

The selected farmer-respondents in rainfed and irrigated situation were homogeneous with respect to the age and family size except land holding and education level. The possession of farm assets and livestock was high in case of irrigated situation compared to rainfed situation. The cropping pattern followed in rainfed and irrigated situation was distinct. Finger millet was an important crop in rainfed situation which occupied around $54 \%$ of gross cropped area, as it can withstand drought conditions. This indicates the importance of finger millet under rainfed condition. Whereas, in irrigated situation finger millet occupied $21.05 \%$ of gross cropped area. 
Cultivation practices adopted by farmers were mapped to know the lacunas in the technologies followed by farmers and identify the gaps in some of the quantifiable variables in comparison with the recommended practices. Results indicated that, both in rainfed (N: 105.2, P: 65.3, K: $1 \mathrm{~kg} / \mathrm{ha}$ ) and irrigated (N: 142, P: 54.2, K: $1.3 \mathrm{~kg} / \mathrm{ha}$ ) situation, application of nitrogen and phosphorous was higher than the recommended dose (rainfed $=$ $\mathrm{N}: 50, \mathrm{P}: 45, \mathrm{~K}: 40 \mathrm{~kg} / \mathrm{ha}$; irrigated $=\mathrm{N}: 100, \mathrm{P}: 50, \mathrm{~K}: 50 \mathrm{~kg} / \mathrm{ha}$ ) as farmers perceived higher application of fertilizers leads to higher yield. Although farmers applied more fertilizers the yield under rainfed and irrigated situation (18.5 and $31.6 \mathrm{q} / \mathrm{ha}$, respectively) was less than the recommended ( 22.5 and $32.5 \mathrm{q} / \mathrm{ha}$, respectively) and it is a point of double loss to farmers in terms of both, excess cost incurred due to higher usage of fertilizer as well as reduced returns due to lower yield compared to recommended. Hence, there is a need to strengthen extension/outreach programmes to create awareness among farmers to use the optimum level of nutrients, which helps in reducing the cost incurred by farmers as well as subsidy burden on government In rainfed situation, 27 $\mathrm{kg}$ of seeds were used per hectare which was two times higher than the recommended $(12.5 \mathrm{~kg} / \mathrm{ha})$. Whereas, in irrigated situation farmers were using seeds $(20.63 \mathrm{~kg} / \mathrm{ha})$ four times higher than the recommended $(5 \mathrm{~kg} / \mathrm{ha})$.

Per hectare cost of cultivation of finger millet was Rs. 48,575 and Rs. 64,369 in rainfed and irrigated situation, respectively. Variable costs accounted for about $80 \%$ in finger millet cultivation indicating that finger millet is not a capital intensive crop. Analysis of cost structure revealed that Rs. 17,651 (36.34\%) and Rs. 23,641 (36.73\%) of total cost of cultivation was incurred on labour in rainfed and irrigated situation, respectively indicating that finger millet though not capital intensive is a labour intensive crop. To reduce the problems faced by small farmers regarding labour availability, efforts should be made by the scientists to develop and promote suitable farm mechanization technologies.

The cost of production was Rs. 2624/q under rainfed situation and Rs. 2040/q under irrigated situation. But the existing procurement price for finger millet was Rs. 2100 per quintal (Government of Karnataka) and Rs. 1650 per quintal (Minimum Support Price of Government of India) fails to cover the cost of production of finger millet under rainfed situation. In the total land holding, the area under finger millet accounted for major (64\%) share in rainfed situation, indicating finger millet is mainly cultivated as rainfed crop and thus the procurement price must be fixed looking into the cost of production of rainfed finger millet. Further, lack of remunerative price which fails to cover the cost of cultivation and provide reasonable profit margin to small farmers acts as disincentive to grow finger millet. Low yield combined with low price leads to reduced returns is one of the main reasons for farmers reducing area under finger millet. Hence, Government should increase the procurement price at least to cover its cost of production in order to help the small famers to continue to grow finger millet. Further, lack of remunerative price which fails to cover the cost of cultivation and provide reasonable profit margin to small farmers acts as disincentive to grow finger millet.Low yield combined with low price leads to reduced returns is one of the main reasons for farmers reducing area under finger millet. Hence, Government should increase the procurement price at least to cover its cost of production in order to help the small famers to continue to grow finger millet.

There is a high demand for finger millet malt due to its high nutritional value with appealing flavor and taste. Finger millet possesses tremendous potential for product diversification. The potential for export of finger millet in the form of grain, flour and value added products needs to be explored. Thus, there is a need to discover the markets for augmenting the exports through organizing trade fairs, exhibitions to create awareness and also gain knowledge about the quality preference and thereby plan measures to promote finger millet exports.

\section{Acknowledgements}

The Authors wish to thank, farmers for sparing their valuable time in providing precious information and Department of Biotechnology, Ministry of Agriculture, Government of India (Grant No. BT/IC-2/ISCB/Phase-IV/03/RAGI/2014 dated: 23-01-2015) for the financial support for the duration of three years (2015-16 to 2017-18) under Indo-Swiss collaboration in Biotechnology.

\section{References}

Acharya, S. P., Basavaraja, H., Kunnal, L. B., Mahajanashetti, S. B., \& Bhat, A. R. S. (2012). Growth in area, production and productivity of major crops in Karnataka. Karnataka Journal of Agricultural Sciences, 25(4), 431-436.

Bairwa, K. C., Sharma, R., \& Kumar, T. (2012). Economics of growth and instability: Fruit crops of India. Rajasthan Journal of Extension Education, 20, 128-132.

Divya, G. M. (2011). Growth and instability analysis of finger millet crop in Karnataka (Unpublished master's thesis, University of Agricultural Sciences, Bengaluru, India). 
Global Facilitation Unit for Underutilized Species. (2014). Minor millets enabling deployment of underutilized species. Retrieved from http://www.nuscommunity.org/uploads/tx_news/Minor_Millet_Brochure.pdf

Government of Karnataka. (2007). Improving the Economic Condition of Farmers. Retrieved from http://raitamitra.kar.nic.in/Karnataka\%20Mission.pdf

Gupta, A. (2006). Improvement of millets and pseudo-cereals in hill region. Sustainable Production from Watershed in NWH (pp. 163-174). Vivekananda Parvatiya Krishi Anusandhan Sansthan, Almora, Uttarakhand.

Jimjel, Z., Rakesh, S., Madhusudan, B., Singh, O. P., \& Dayakar, B. (2015). Production cost and return: Comparative analysis of sorghum in India and Nigeria. Economics, 4(2), 18-21. https://doi.org/10.11648/ j.eco. 20150402.11

Kannan, E. (2011). Trends in India's agricultural growth and its determinants. Asian Journal of Agriculture and Development, 8(2), 79-99.

Kumar, S. R. K. P., \& Ranjan, P. (1998). Growth and instability in production of principal food grain crops: A case of backward economy. Bangladesh Journal of Agricultural Economics, 21(1\&2), 1-20.

Kumawat, R. C., \& Meena, P. C. (2005). Growth and instability in area, production and yield of major spice crops in Rajasthan vis-à-vis India. Journal of Spices and Aromatic Crops, 14(2), 102-111.

Lal, H., \& Sharma, K. D. (2006). Economics of potato production in Lahaul valley of Himachal Pradesh. Potato Journal, 33(3-4), 139-143.

Michaelraj, S. J. P., \& Shanmugam, A. (2013). A study on millets based cultivation and consumption in India. International Journal of Marketing, Financial Services \& Management Research, 2(4), 49-58.

Millet Network of India-Deccan Development Society-FIAN. (2009). Millets-Future of food \& Farming. Retrieved from http://shikshantar.org/sites/default/files/PDF/MILLETS\%2520Future\%2520of\%2520food\% 2520and\%2520farming.pdf

Narayanamoorthy, A. (2013). Profitability in crops cultivation in India: Some evidence from cost of cultivation survey data. Indian Journal of Agricultural Economics, 68(1), 104-121.

Pant, M., \& Srivastava, S. K. (2014). Economics of finger millet cultivation in hills of Kumaon region of Uttarakhand. Journal of Hill Agriculture, 5(1), 13-18. https://doi.org/10.5958/2230-7338.2014.00831.3

Rajpurohit, A. (1983). Recent trends in agricultural growth rates in Karnataka. Indian Journal of Agricultural Economic, 38(2), 585-590.

Sakamma, S., \& Ananth, G. S. (2011). Growth and Instability in Production and Export of Major Spices of India: An Economic Analysis. Green Farming, 2(5), 615-617.

The New India Express. (2015). Scientists work on tweaking ragi to increase yield, nutrition. Retrieved from http://www.newindianexpress.com/states/karnataka

Vinayaka, K., Lokapur, S., Gurikar, R., \& Hosali, R. (2014). Growth and instability analysis of fruits crops in India-An economic analysis. Journal of Environmental Science, Computer Science and Engineering \& Technology, 3(4), 1808-1813.

Supplementary Materials:

http://www.agritech.tnau.ac.in

http://www.thefitindian.com

http://www.millets.res.in

http://www.indiastat.com

http://www.fao.org

http://des.kar.nic.in

\section{Copyrights}

Copyright for this article is retained by the author(s), with first publication rights granted to the journal.

This is an open-access article distributed under the terms and conditions of the Creative Commons Attribution license (http://creativecommons.org/licenses/by/4.0/). 